\title{
Zastosowanie techniki spektroskopii w podczerwieni (FT-IR) do oceny stanu zanieczyszczenia gleb węglowodorami
}

\begin{abstract}
W artykule omówiono etapy doboru odpowiednich warunków metody oznaczania sumarycznej zawartości węglowodorów w glebie z zastosowaniem spektroskopii w podczerwieni. W wyniku przeprowadzonych badań dobrano sposób wyznaczania tła oraz określono wpływ zmiany kuwety. Wybrano substancję wzorcową, warunki prowadzenia ekstrakcji, dobrano także odpowiednią wielkość próbki analitycznej. Sprawdzono wpływ potencjalnie występujących w próbce interferentów na wynik badań. Opracowana metoda może być stosowana in situ i jest dobrą alternatywą dla standardowo używanych do oznaczania zawartości węglowodorów metod chromatograficznych.
\end{abstract}

Słowa kluczowe: gleba, FT-IR, zanieczyszczenie węglowodorami.

\section{Application of Infrared Spectroscopy (FT-IR) to assess the state of soil contamination by hydrocarbons}

The article discusses the steps in the selection of appropriate conditions for the method of determining the total content of hydrocarbons in the soil, using infrared spectroscopy. As a result of research, a method for determining the background and identifying the impact of cell changes were selected. There were also selected, reference substance, the conditions for conducting extraction and analytical sample size. Also examined, was the potential effect of interfering substances presented in the sample on the results. The developed method can be used "in situ" and is a good alternative for chromatographic methods used for the determination of hydrocarbon content.

Key words: soil, FT-IR, contamination by hydrocarbons.

\section{Wstęp}

Najczęściej stosowanymi metodami znormalizowanymi do oznaczania zawartości grup węglowodorów w próbkach ciekłych i stałych są metody chromatograficzne, w których wykorzystuje się różnego typu detektory oraz różnorodne warunki ekstrakcji [5-13]. Metody te są czasochłonne, wymagają złożonej preparatyki próbki przed analizą, a transport aparatury pomiarowo-badawczej w przypadku metod chromatograficznych nie jest możliwy $[2,4]$. Z tych względów, w celu określania zawartości węglowodorów w glebie w warunkach polowych, zastosowana została nieinwazyjna prosta technika - spektroskopia w podczerwieni (FT-IR). Metoda ta pozwala oznaczyć sumaryczną zawartość węglowodorów (benzynowych, olejowych oraz jedno- i wielo- pierścieniowych węglowodorów aromatycznych). Nie może być zatem stosowana wówczas, gdy konieczne jest odniesienie wyników analizy do Rozporządzenia Ministra Środowiska z dnia 9 września 2002 r. w sprawie standardów jakości gleby oraz standardów jakości ziemi (Dz. U. z 2002 r. nr 165, poz. 1359) [14], które wymaga wyodrębnienia każdej ze wspomnianych grup, a w przypadku węglowodorów aromatycznych - podania także zawartości poszczególnych węglowodorów.

Badania służące optymalizacji opisywanej metody zostały przeprowadzone przy użyciu spektrometru FT-IR (model Spectrum Two, firmy PerkinElmer). Za pomocą wymienionego aparatu mierzono sumaryczną zawartość węglowodorów 
wyekstrahowanych z próbek gleb przy użyciu rozpuszczalnika organicznego (tetrachloroetylenu - TCE). Wybranie TCE do ekstrakcji węglowodorów było spowodowane możliwością uzyskania dużo większej czułości metody niż podczas badań z zastosowaniem cykloheksanu, a także brakiem konieczności używania specjalnej kuwety (solnej) do wykony- wania pomiarów. Rejestracji i analizy widm dokonano przy użyciu programu Spectrum 10 Software. Następnie dla każdego z widm wyznaczono wartość absorbancji dla pików w zakresie długości fali $2947 \div 2882 \mathrm{~cm}^{-1}$. Wykorzystując klasyczną analizę regresji, skonstruowano zależność danych spektralnych od zawartości węglowodorów.

\section{Opracowanie metody oznaczania zawartości węglowodorów w glebach techniką spektroskopii w podczerwieni (FT-IR)}

Pierwszym etapem opracowania i optymalizacji metody oznaczania sumarycznej zawartości węglowodorów w glebie było ustalenie sposobu wyznaczenia tła pomiarowego. Zgodnie z zaleceniem producenta aparatu należało wykonać badania względem powietrza, co powinno zwiększyć czułość metody. Natomiast standardowym postępowaniem w przypadku metod spektrofotometrycznych jest wykonywanie pomiarów względem rozpuszczalnika niezawierającego analitu. W związku z powyższym sprawdzono wpływ rodzaju tła na przebieg krzywych wzorcowych. Sporządzono dwie krzywe wzorcowania w zakresie stężeń od 30 do $500 \mathrm{mg} / 1$ węglowodorów. Dla jednej z krzywych pomiary absorbancji wykonano względem powietrza, a dla drugiej tło pomiarowe stanowił tetrachloroetylen (TCE). Otrzymane krzywe zostały przedstawione na rysunku 1 .

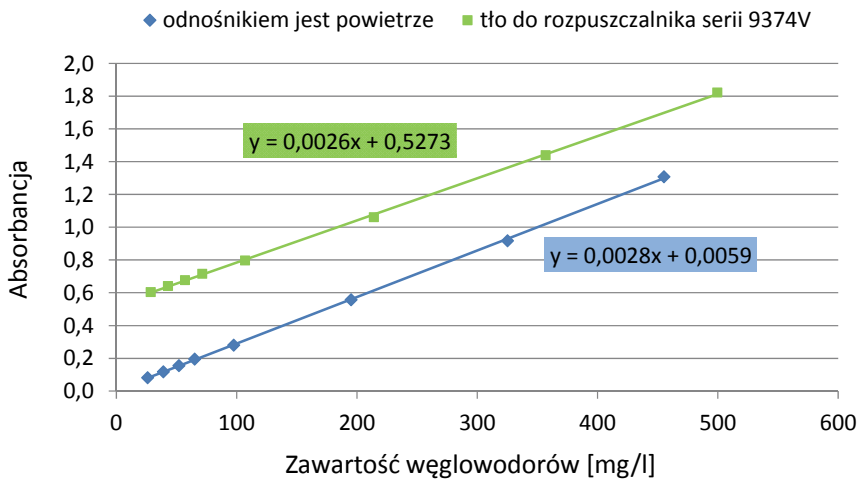

Rys. 1. Wpływ rodzaju tła pomiarowego na przebieg krzywych wzorcowania

Wartości współczynnika kierunkowego otrzymanych krzywych wzorcowania (rysunek 1) są do siebie zbliżone $(0,0026$ oraz 0,0028$)$, co świadczy o braku wpływu rodzaju tła pomiarowego na czułość metody. Zastosowanie powietrza jako odnośnika wymaga jednak powtórzenia kalibracji po każdej zmianie serii produkcyjnej rozpuszczalnika stosowanego do wykonywania oznaczeń. Użycie rozpuszczalnika z innej serii zmienia bowiem przebieg krzywych, co zostało przedstawione na rysunku 2 .

Oznaczenie zawartości węglowodorów względem powietrza, przy użyciu rozpuszczalnika innej serii produkcyjnej

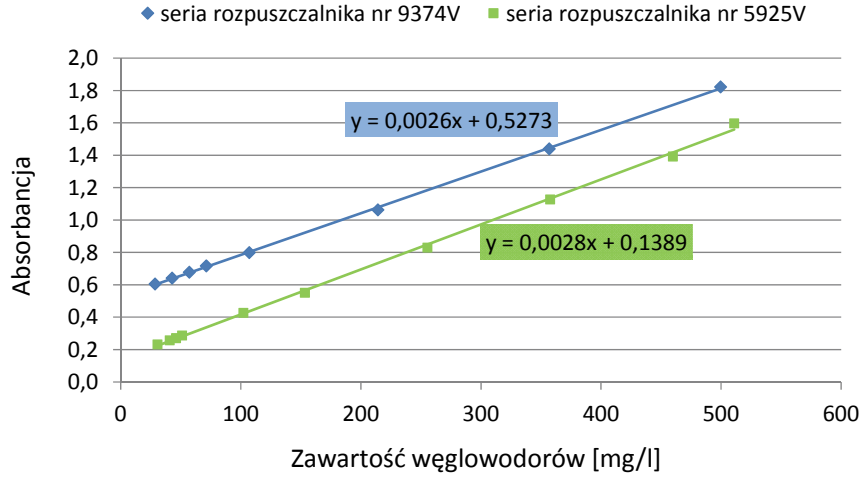

Rys. 2. Porównanie przebiegu krzywych wzorcowania uzyskanych względem powietrza dla dwóch różnych serii rozpuszczalnika

niż zastosowana przy konstruowaniu krzywej wzorcowania, może być źródłem błędów systematycznych wynoszących nawet 50\%. Konieczność wykonania ponownego wzorcowania przy każdej zmianie serii rozpuszczalnika oraz możliwość powstania błędów systematycznych przy stosowaniu powietrza jako tha pomiarowego spowodowały, że dalsze pomiary służące opracowaniu metody oznaczania zawartości węglowodorów wykonywano względem rozpuszczalnika (TCE).

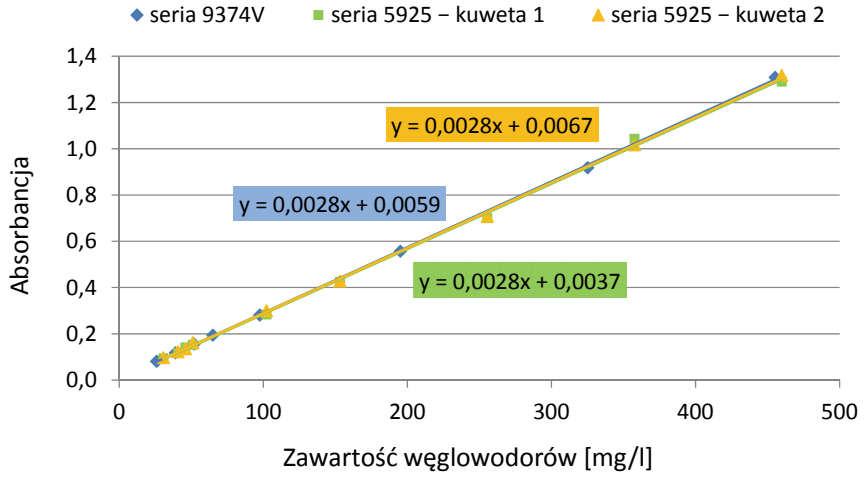

Rys. 3. Wpływ serii produkcyjnej rozpuszczalnika (TCE) stosowanego jako tło pomiarowe oraz wykorzystania innej kuwety pomiarowej na przebieg krzywych wzorcowania

Do wzorcowania spektrometru i właściwego oznaczania powinna być używana ta sama kuweta, aby wykluczyć błędy wynikające ze zmiany długości drogi optycznej [1]. Sprawdzono 
więc czy zastosowanie innej kuwety do wykonywania pomiarów niż używana do wzorcowania wpływa w znaczący sposób na wynik oznaczenia. W obydwu przypadkach zastosowano kuwety kwarcowe o długości drogi optycznej $1 \mathrm{~cm}$. Zmiana kuwety nie powoduje błędów większych niż 1,5\% (rysunek 3). Zastosowanie w praktyce laboratoryjnej więcej niż jednej kuwety pomiarowej wymaga jednak każdorazowo sprawdzenia, czy wybrane do badań kuwety będą cechować się taką samą charakterystyką.

Kolejnym etapem opracowania metody oznaczania sumarycznej zawartości węglowodorów w glebie metodą FT-IR był dobór odpowiedniej substancji wzorcowej. Dostępne w handlu materiały referencyjne nie są odpowiednie do stosowania w metodzie FT-IR, ponieważ zawierają rozpuszczalniki inne niż tetrachloroetylen (np. metanol). Użyte wzorce zostały przygotowane w laboratorium przez rozpuszczenie w tetrachloroetylenie benzyny silnikowej, oleju napędowego lub pojedynczego czystego węglowodoru, dostępnego jako substancja stała $\left(\mathrm{C}_{19}\right)$. Wybór tych substancji był podyktowany ich łatwą dostępnością oraz tym, że reprezentują grupy węglowodorów, których zawartość w glebie jest określona w rozporządzeniu [14]. Z uwagi na wysoką toksyczność jedno- i wielopierścieniowych węglowodorów aromatycznych zrezygnowano ze stosowania ich jako wzorców. Wzorcowanie spektrometru przeprowadzono z użyciem każdego z trzech wybranych wzorców w zakresie od około 30 do około $600 \mathrm{mg} / 1$. Otrzymane krzywe przedstawiono na rysunku 4.

$\mathrm{Z}$ przeprowadzonych badań wynika, że wszystkie funkcje wzorcowania są liniowe, o czym świadczą współczynni-

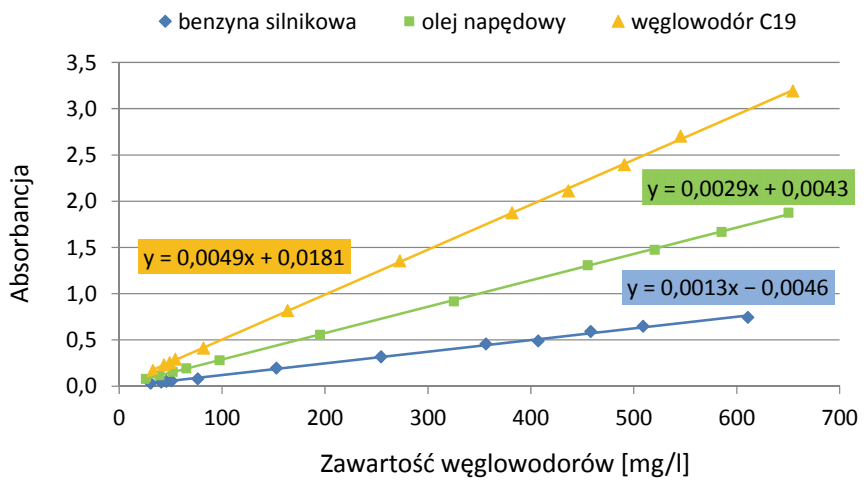

Rys. 4. Porównanie przebiegu krzywych wzorcowania uzyskanych dla trzech różnych substancji wzorcowych

ki determinacji $r$ mieszczące się w zakresie od 0,9989 (dla benzyny) do 0,9999 (dla oleju napędowego oraz węglowodoru $\mathrm{C}_{19}$ ). Badania wykazały natomiast, że czułość metody zależy od wzorca użytego podczas wzorcowania (rysunek 4). Największą czułość uzyskano dla pojedynczego czystego węglowodoru, natomiast najniższą dla benzyny (mieszanina lekkich węglowodorów).

Zanieczyszczenia węglowodorowe próbek rzeczywistych stanowią zwykle mieszaninę węglowodorów z różnych grup. Przed wykonaniem analizy nie można stwierdzić, które węglowodory się w nich znajdują i dobranie odpowiedniej substancji wzorcowej może być trudne.

W celu oceny wpływu rodzaju wzorca na otrzymane wyniki badań przeprowadzono pomiary dla roztworów o znanej zawartości jednego z trzech analitów: benzyny, oleju lub węglowodoru $\mathrm{C}_{19}$. Następnie zawartość węglowodorów w tych

Tablica 1. Wyniki oznaczenia zawartości węglowodorów w roztworach z wykorzystaniem różnych krzywych kalibracyjnych

\begin{tabular}{|c|c|c|c|c|c|c|c|c|c|}
\hline & \multicolumn{3}{|c|}{$\begin{array}{l}\text { Wzorcowanie z użyciem } \\
\text { benzyny silnikowej }\end{array}$} & \multicolumn{3}{|c|}{$\begin{array}{c}\text { Wzorcowanie z zastosowaniem } \\
\text { oleju napędowego }\end{array}$} & \multicolumn{3}{|c|}{$\begin{array}{l}\text { Wzorcowanie z użyciem } \\
\text { węglowodoru } \mathrm{C}_{19}\end{array}$} \\
\hline \multicolumn{10}{|c|}{ Analit: benzyna silnikowa } \\
\hline Założone stężenie analitu [mg/l] & 52,6 & 263,1 & 631,5 & 52,6 & 263,1 & 631,5 & 52,6 & 263,1 & 631,5 \\
\hline Oznaczone stężenie analitu [mg/l] & 61,4 & 283,5 & 682,4 & 27,5 & 122,1 & 291,9 & 12,8 & 73,5 & 181 \\
\hline Błąd względny [\%] & 16,7 & 7,8 & 8,1 & $-47,7$ & $-53,6$ & $-53,8$ & $-75,7$ & $-72,1$ & $-71,3$ \\
\hline Błąd bezwzględny [mg/l] & 8,8 & 20,4 & 50,9 & $-25,1$ & $-141,0$ & $-339,6$ & $-39,8$ & $-189,6$ & $-450,5$ \\
\hline \multicolumn{10}{|c|}{ Analit: olej napędowy } \\
\hline Założone stężenie analitu [mg/l] & 58,2 & 290,9 & 698,2 & 58,2 & 290,9 & 698,2 & 58,2 & 290,9 & 698,2 \\
\hline Oznaczone stężenie analitu [mg/l] & 142,0 & 667,2 & 1613,4 & 62,0 & 286,0 & 687,1 & 32,5 & 165,5 & 403,9 \\
\hline Błąd względny [\%] & 144,0 & 129,4 & 131,1 & 6,5 & $-1,7$ & $-1,6$ & $-44,2$ & $-43,1$ & $-42,2$ \\
\hline Błąd bezwzględny [mg/l] & 83,8 & 376,3 & 915,2 & 3,8 & $-4,9$ & $-11,1$ & $-25,7$ & $-125,4$ & $-294,3$ \\
\hline \multicolumn{10}{|c|}{ Analit: węglowodór $\mathrm{C}_{19}$} \\
\hline Założone stężenie analitu [mg/l] & 53,0 & 264,8 & 635,4 & 53,0 & 264,8 & 635,4 & 53 & 264,8 & 635,4 \\
\hline Oznaczone stężenie analitu [mg/l] & 213,5 & 1027,1 & 2474,4 & 92,5 & 439,4 & 1056,2 & 50,6 & 256,4 & 622,8 \\
\hline Błąd względny [\%] & 302,8 & 287,9 & 289,4 & 74,5 & 65,9 & 66,2 & $-4,5$ & $-3,2$ & $-2,0$ \\
\hline Błąd bezwzględny [mg/l] & 160,5 & 762,3 & 1839,0 & 39,5 & 174,6 & 420,8 & $-2,4$ & $-8,4$ & $-12,6$ \\
\hline
\end{tabular}


roztworach została wyznaczona w oparciu o trzy krzywe wzorcowania sporządzone przy użyciu trzech różnych wzorców. Efekty badań przedstawiono w tablicy 1, w której zestawiono otrzymane wyniki z wartością odniesienia, czyli z założonym stężeniem analitu wyznaczonym wagowo.

Najmniejsze wartości błędów względnych uzyskano dla stężeń oznaczanego analitu, obliczonego na podstawie krzywej skonstruowanej z wykorzystaniem tej samej substancji co oznaczana w próbce. Dobranie optymalnego wzorca do wzorcowania w przypadku próbek rzeczywistych o nieznanym składzie jakościowym jest jednak trudne. Ponadto skażenia próbek rzeczywistych z reguły są spowodowane mieszaniną węglowodorów, dlatego też odrzucono węglowodór $\mathrm{C}_{19}$ jako wzorzec. Spośród pozostałych dwóch wzorców wybrano olej. Wynika to z faktu, że zanieczyszczenia odpadów wiertniczych, mogące przedostać się do gleby, stanowią głównie węglowodory olejowe [3]. Ponadto współczynnik kierunkowy krzywej wzorcowej uzyskanej przy zastosowaniu oleju jest ponad dwukrotnie wyższy niż krzywej wzorcowej otrzymanej dla benzyny. Użycie oleju napędowego zwiększyło zatem czułość metody.
Dalszym etapem opracowania procedury oznaczania zawartości węglowodorów w glebie metodą spektroskopii w podczerwieni było ustalenie optymalnych warunków ekstrakcji. W metodach chromatograficznych lekkie węglowodory $\left(\right.$ do $\mathrm{C}_{12}$ ) są ekstrahowane do fazy nadpowierzchniowej metodą head-space, natomiast cięższe wydzielane z gleby za pomocą ekstrakcji ciecz-ciało stałe. W przypadku oznaczania zawartości węglowodorów metodą FT-IR wszystkie węglowodory są ekstrahowane przy użyciu jednego rozpuszczalnika (TCE). W celu dobrania odpowiednich warunków ekstrakcji węglowodorów przygotowano próbki gleby zanieczyszczone w różnym stopniu olejem napędowym, które następnie poddano ekstrakcji w warunkach opisanych w tablicy 2.

Następnie próbki gleby o identycznej zawartości węglowodorów poddano ekstrakcjom wszystkimi sprawdzanymi sposobami. W badaniach wykorzystano próbki syntetyczne (uzyskane w laboratorium poprzez odpowiednie zanieczyszczenie gleby) oraz próbkę rzeczywistą.

Wyniki optymalizacji sposobu ekstrakcji węglowodorów z gleby przedstawiono w tablicy 3 oraz dla wybranych poziomów stężeń na rysunkach 5 i 6.

Tablica 2. Sposoby przeprowadzania ekstrakcji węglowodorów z gleby

\begin{tabular}{|c|c|}
\hline $\begin{array}{c}\text { Sposób } \\
\text { ekstrakcji nr }\end{array}$ & Warunki ekstrakcji węglowodorów z gleby do tetrachloroetylenu w metodzie FT-IR \\
\hline 1 & 2,5 g próbki $+5 \mathrm{ml}$ rozpuszczalnika; czas $24 \mathrm{~h}$ bez wspomagania ultradźwiękami \\
\hline 2 & $2,5 \mathrm{~g}$ próbki $+5 \mathrm{ml}$ rozpuszczalnika; czas 1 minuta ręcznego wytrząsania \\
\hline 3 & 2,5 g próbki $+5 \mathrm{ml}$ rozpuszczalnika; czas 15 minut z zastosowaniem ekspozycji ultradźwiękowej \\
\hline 4 & 2,5 g próbki $+5 \mathrm{ml}$ rozpuszczalnika; czas 30 minut ze wspomaganiem ultradźwiękami \\
\hline 5 & 2,5 g próbki $+5 \mathrm{ml}$ rozpuszczalnika; czas 60 minut ze wspomaganiem ultradźwiękami \\
\hline 6 & 2,5 g próbki $+\mathrm{NaCl}+5 \mathrm{ml}$ rozpuszczalnika; czas 30 minut ze wspomaganiem ultradźwiękami \\
\hline 7 & 2,5 g próbki $+\mathrm{NaCl}$ oraz $\mathrm{HCl}+5$ ml rozpuszczalnika; czas 30 minut ze wspomaganiem ultradźwiękami \\
\hline 8 & 2,5 g próbki $+\mathrm{dwie}$ porcje rozpuszczalnika po $5 \mathrm{ml}$; czas $30+15$ minut ze wspomaganiem ultradźwiękami \\
\hline 9 & 2,5 g próbki $+10 \mathrm{ml}$ rozpuszczalnika; czas 30 minut z zastosowaniem ekspozycji ultradźwiękowej \\
\hline
\end{tabular}

Tablica 3. Wyniki dobierania optymalnych warunków ekstrakcji węglowodorów z gleby

\begin{tabular}{|c|r|r|r|r|r|r|r|r|r|r|}
\hline $\begin{array}{c}\text { Założony poziom } \\
\text { stężenia analitu }\end{array}$ & Sposób 1 & Sposób 2 & Sposób 3 & \multicolumn{2}{c|}{ Sposób 4 } & Sposób 5 & Sposób 6 & Sposób 7 & Sposób 8 & Sposób 9 \\
\hline \multicolumn{7}{|c|}{ [mg/kg] } & \multicolumn{7}{|c|}{ Odzysk [\%] } \\
\hline 100 & 77,2 & 114,3 & 107,9 & 93,5 & 61,4 & 132,9 & 170,8 & 323,5 & 102,6 \\
\hline 150 & 106,5 & 104,5 & 93,0 & 100,2 & 102,8 & 137,5 & 114,0 & 127,5 & 143,5 \\
\hline 200 & 122,3 & 104,4 & 92,4 & 94,5 & 93,5 & 105,9 & 108,3 & 118,1 & 110,2 \\
\hline 300 & 96,2 & 89,3 & 108,8 & 84,5 & 114,2 & 113,0 & 119,7 & 155,5 & 45,7 \\
\hline 1000 & 133,4 & 76,2 & 91,8 & 77,8 & 104,4 & 102,9 & 101,0 & 159,4 & 83,2 \\
\hline 3000 & 103,7 & 64,0 & 89,5 & 78,0 & 58,6 & 87,4 & 99,1 & 112,0 & 84,6 \\
\hline 5000 & 86,8 & 79,8 & 82,4 & 79,1 & 83,0 & 82,5 & 81,9 & 95,8 & 82,5 \\
\hline $\begin{array}{c}750 \\
\text { (próbka }\end{array}$ & 171,5 & 63,7 & 86,1 & 100,3 & 100,3 & 91,7 & 47,7 & 123,9 & 147,4 \\
\hline
\end{tabular}




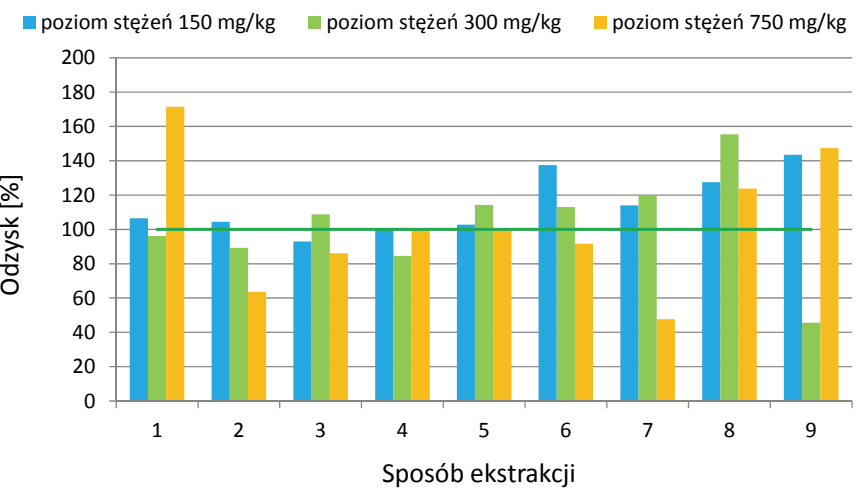

Rys. 5. Porównanie wydajności ekstrakcji węglowodorów z gleby dla próbek z zakresu niskich poziomów stężeń węglowodorów w glebie

— poziom stężeń $1000 \mathrm{mg} / \mathrm{kg}$ ॥ poziom stężeń $3000 \mathrm{mg} / \mathrm{kg}$ 『poziom stężeń $5000 \mathrm{mg} / \mathrm{kg}$

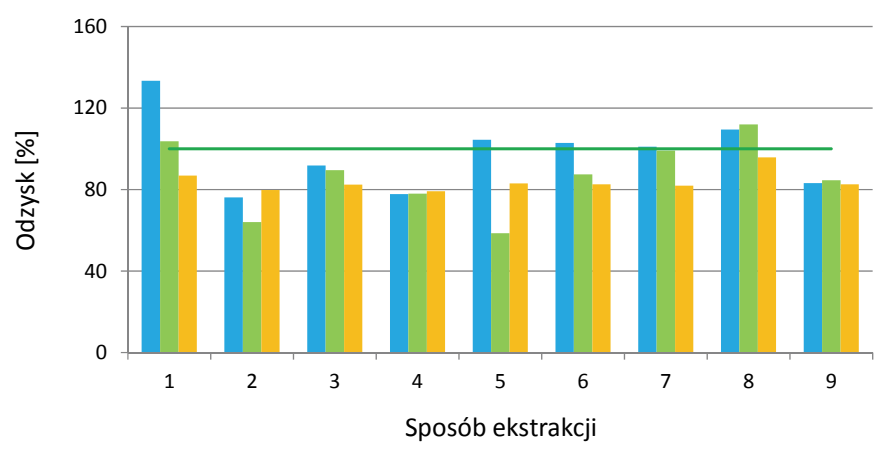

Rys. 6. Wydajność procesu ekstrakcji węglowodorów z gleby przeprowadzonej różnymi sposobami dla wysokich poziomów stężeń węglowodorów w glebie stopniu, natomiast ekstrakcja sposobem 8 jest właściwa dla próbek bardziej zanieczyszczonych.

Wybór warunków ekstrakcji węglowodorów odbywał się głównie przy zastosowaniu próbek syntetycznych, sporządzonych w laboratorium, z których przygotowano próbki analityczne o masie wynoszącej 2,5 g. Zbyt mała masa w przypadku niejednorodnych próbek rzeczywistych może przyczynić się do otrzymania dużego rozrzutu między wynikami i zwiększyć niepewność analizy. W związku z tym następnym etapem opracowywania procedury oznaczania zawartości węglowodorów w glebie metodą spektroskopii w podczerwieni było dobranie odpowiedniej wielkości próbki analitycznej używanej do oznaczenia. Przyjęto założenie, że optymalny stosunek gleby do rozpuszczalnika wynosi 1:2. Potwierdziły to badania nad warunkami i wydajnością ekstrakcji. Taka proporcja nie powoduje nadmiernego rozcieńczenia analitu i pozwala uzyskać ilość ekstraktu odpowiednią do badań. Ponadto wykonano badania w próbkach rzeczywistych przy założonym stosunku gleby do rozpuszczalnika, zmieniając wyjściową masę próbki od $2,5 \mathrm{~g}$ do 10 g. Określono powtarzalność metody na podstawie 10 pomiarów wykonanych dla każdej z otrzymanych serii. Powtarzalność wyrażono jako względne odchylenie standardowe (RSD). Wyniki badań zebrano w tablicy 4.

Największą precyzję (RSD około 14\%) i dokładność metody (błąd względny równy $6 \%$ ) uzyskano dla próbek o masie $5,0 \mathrm{~g}$.
Najwydajniejsze ekstrakcje zostały osiągnięte przy zastosowaniu sposobów ekstrakcji od 3 do 6 (dla stężeń węglowodorów nieprzekraczających $1 \mathrm{~g} / \mathrm{kg}$ ). W przypadku próbki rzeczywistej o stężeniu węglowodorów wynoszącym $750 \mathrm{mg} / \mathrm{kg}$ najefektywniejsze ekstrakcje przeprowadzono metodami 4 i 5. Dla stężeń wyższych niż $1 \mathrm{~g} / \mathrm{kg}$ wydajność ekstrakcji wzrosła na skutek zwiększenia ilości rozpuszczalnika z $5 \mathrm{ml}$ do $10 \mathrm{ml}$. Dwoma optymalnymi sposobami ekstrakcji, które wybrano na podstawie przeprowadzonych badań, są: sposób 4 (ekstrakcja gleby rozpuszczalnikiem w stosunku 1:2, w czasie 30 minut, wspomagana ultradźwiękami) oraz sposób 8 (ekstrakcja ultradźwiękowa, prowadzona w dwóch etapach dwiema porcjami rozpuszczalnika, w czasie 45 minut). Sposób 4 uznano za odpowiedni dla próbek niezanieczyszczonych lub zanieczyszczonych węglowodorami w nieznacznym
Tablica 4. Dobór odpowiedniej naważki gleby

\begin{tabular}{|c|c|c|c|c|}
\hline $\begin{array}{c}\text { Masa } \\
\text { próbki } \\
{[\mathrm{g}]}\end{array}$ & $\begin{array}{c}\text { Objętość } \\
\text { rozpuszczalnika } \\
{[\mathrm{ml}]}\end{array}$ & $\begin{array}{c}\text { Otrzymany wynik } \\
\text { oznaczenia } \\
{[\mathrm{mg} / \mathrm{kg}]}\end{array}$ & $\begin{array}{c}\text { Błąd } \\
\text { względny } \\
{[\%]}\end{array}$ & $\begin{array}{c}\text { Względne odchylenie } \\
\text { standardowe RSD } \\
{[\%]}\end{array}$ \\
\hline 2,5 & 5,0 & 692,7 & 8,5 & 15,3 \\
\hline 5,0 & 10,0 & 711,8 & 6,0 & 13,9 \\
\hline 10,0 & 20,0 & 554,4 & 26,8 & 20,3 \\
\hline
\end{tabular}

Tablica 5. Wpływ substancji przeszkadzających na wynik oznaczenia zawartości węglowodorów w glebie

\begin{tabular}{|l|c|c|c|}
\hline Dodany interferent & $\begin{array}{c}\text { Objętość substancji } \\
\text { przeszkadzającej } \\
\text { dodana do 5,0 g } \\
\text { próbki gleby } \\
{[\mu \mathrm{l}]}\end{array}$ & $\begin{array}{c}\text { Zawartość węglowodorów } \\
\text { w próbce gleby (średnia } \\
\text { arytmetyczna z trzech } \\
\text { niezależnych oznaczeń) } \\
{[\mathrm{g} / \mathrm{kg}]}\end{array}$ & $\begin{array}{c}\text { Odzysk } \\
{[\%]}\end{array}$ \\
\hline- & - & 17,8 & - \\
\hline Metanol & 20 & 18,7 & 105 \\
\hline Metanol & 100 & 17,6 & 99 \\
\hline Izopropanol & 20 & 16,2 & 91 \\
\hline Izopropanol & 100 & 13,1 & 74 \\
\hline Glikol polietylenowy & 20 & 19,1 & 107 \\
\hline Glikol polietylenowy & 100 & 18,5 & 104 \\
\hline
\end{tabular}


W ramach opracowywania metody sprawdzono również wpływ matrycy (substancji przeszkadzających) na wynik oznaczenia. $\mathrm{W}$ tym celu do próbek gleby $\mathrm{z}$ dodatkiem oleju wprowadzono jeden z potencjalnych interferentów (metanol, izopropanol lub glikol polietylenowy). Wybór tych substancji wynikał z możliwości skażenia nimi gleby oraz ich przypuszczalnego wpływu na sygnał analityczny. Pomiary wykonano dla dwóch różnych poziomów zawartości substancji przeszkadzających. Pierwszy z nich wynosił około $20 \%$ zawartości analitu w próbce, drugi był zbliżony do zawartości analitu w próbce. Otrzymane wyniki zestawiono w tablicy 5.
Dodatek metanolu i glikolu polietylenowego nie wpłynął w istotny sposób na wynik oznaczenia węglowodorów (odzysk w granicach 99 $\div 107 \%$ ). W przypadku próbek zawierających dodatek i-propanolu wydajność ekstrakcji znacząco spadła, nawet do $74 \%$. Należy pamiętać jednak o tym, że i-propanol w próbkach gleby występuje w niewielkich ilościach, stąd też w próbkach rzeczywistych zawartość i-propanolu powinna być znacznie niższa niż koncentracja analitu. W związku z tym jego obecność w istotny sposób nie przeszkodzi w prowadzeniu pomiarów opracowaną metodą.

\section{Podsumowanie}

Na podstawie przeprowadzonych badań dobrano następujące warunki dla metody oznaczania węglowodorów w glebie przy użyciu spektroskopii w podczerwieni:

- tło pomiaru: wyznaczane względem rozpuszczalnika,

- substancja wzorcowa: olej napędowy,

- warunki prowadzenia ekstrakcji dla próbek zanieczyszczonych węglowodorami w małym stopniu: ekstrakcja ultradźwiękowa gleby tetrachloroetylenem w stosunku 1:2, czas ekstrakcji: 30 minut,

- sposób ekstrakcji próbek zanieczyszczonych w dużym stopniu: ekstrakcja ultradźwiękowa dwuetapowa, w każdym z etapów stosunek gleby do rozpuszczalnika to $1: 2$, czas trwania pierwszego etapu: 30 minut, a drugiego - 15 minut,
- masa próbki analitycznej: 5,0 g,

- możliwy interferent: izopropanol.

Opracowana metoda oznaczania sumarycznej zawartości węglowodorów w glebie może służyć do prowadzenia pomiarów wskaźnikowych ewentualnych zanieczyszczeń węglowodorowych na terenach przemysłowych. Zaletą tej metody jest jej znacznie mniejsza czasochłonność niż alternatywnych metod chromatograficznych, a także fakt, że może być ona $\mathrm{z}$ powodzeniem stosowana $\mathrm{w}$ warunkach polowych. Metoda ta nie może być jednak wykorzystywana do pełnej diagnostyki zanieczyszczeń węglowodorowych gleby, gdyż nie pozwala na podział węglowodorów na poszczególne grupy zgodnie z wymaganiami rozporządzenia [14].

Prosimy cytować jako: Nafta-Gaz 2016, nr 9, s. 729-735, DOI: 10.18668/NG.2016.09.07

Artykuł nadesłano do Redakcji 29.03.2016 r. Zatwierdzono do druku 6.05.2016 r.

Artykuł powstał na podstawie pracy badawczej pt.: Logistyka i technologie monitoringu oraz sposoby ochrony środowiska przed rozpoczęciem prac, $w$ trakcie wiercenia, w procesach szczelinowania hydraulicznego oraz na etapie eksploatacji, $w$ tym monitoring wód podziemnych, powietrza, hałasu, gleby, emisji gazów i innych - praca INiG - PIB na zlecenie Narodowego Centrum Badań i Rozwoju; nr zlecenia: 6116/GE/13, nr archiwalny: DK-4100-13/13.

\section{Literatura}

[1] Cygański A.: Metody spektroskopowe w chemii analitycznej. Wydawnictwo WNT, Warszawa 2012.

[2] Holewa J., Kusina E., Krasińska A.: Zanieczyszczenia węglowodorowe w zużytych podkładach kolejowych i ich oznaczanie w celu klasyfikacji odpadów. Nafta-Gaz 2008, nr 3, s. 205-211.

[3] Jamrozik A.: Wpływ wybranych czynników chemicznych i fizycznych na właściwości zużytych płuczek wiertniczych. Rozprawa doktorska. Akademia Górniczo-Hutnicza im. St. Staszica, Katedra Wiertnictwa i Geoinżynierii, Kraków 2009.

[4] Janiga M., Kania M.: Oznaczanie związów typu BTEX w wodach metoda chromatografii gazowej, z zastosowaniem techniki Purge and Trap. Nafta-Gaz 2011, nr 10, s. 729-735.

\section{Akty prawne i normatywne}

[5] PN-EN 14039:2008 Charakteryzowanie odpadów. Oznaczanie zawartości węglowodorów w zakresie od $C_{10}$ do $C_{40} z a$ pomoca chromatografii gazowej.
[6] PN-EN 15527:2008 Charakteryzowanie odpadów. Oznaczanie policyklicznych węglowodorów aromatycznych (PAH) wodpadach z uzyciem chromatografii gazowej z detektorem masowym (GC/MS).

[7] PN-EN ISO 15009:2013 Jakość gleby. Oznaczanie zawartości lotnych węglowodorów aromatycznych, naftalenu oraz lotnych weglowodorów halogenowanych metoda chromatografii gazowej. Metoda usuwania i wychwytu z desorpcja termiczna.

[8] PN-EN ISO 15680:2008 Jakość wody. Oznaczanie wybranych jednopierścieniowych węglowodorów aromatycznych, naftalenu i niektórych związków chlorowanych metoda chromatografi gazowej z zastosowaniem techniki wyplukiwania $i$ wyłapywania oraz desorpcji termicznej.

[9] PN-EN ISO 16703:2011 Jakość gleby. Oznaczanie zawartości węglowodorów w zakresie od $C_{10}$ do $C_{40}$ metoda chromatografi gazowej. 
[10] PN-EN ISO 17993:2005 Jakość wody. Oznaczanie 15 wielopierścieniowych węglowodorów aromatycznych (WWA) $w$ wodzie metoda HPLC z detekcja fluorescencyjna po ekstrakcji ciecz-ciecz.

[11] PN-EN ISO 22155:2013 Jakość gleby. Oznaczanie lotnych węglowodorów aromatycznych, lotnych węglowodorów halogenowanych oraz wybranych eterów z zastosowaniem chromatografii gazowej. Metoda statycznej analizy fazy nadpowierzchniowej.

[12] PN-ISO 13877:2004 Jakość gleby. Oznaczanie wielopierścieniowych węglowodorów aromatycznych. Metoda z zastosowaniem wysokosprawnej chromatografii cieczowej.

[13] PN-ISO 18287:2008 Jakość gleby. Oznaczanie zawartości wielopierścieniowych węglowodorów aromatycznych $(P A H)$.

\section{Mgr Jadwiga HOLEWA-RATAJ}

Starszy specjalista badawczo-techniczny w Zakładzie Ochrony Środowiska.

Instytut Nafty i Gazu - Państwowy Instytut Badawczy

ul. Lubicz 25 A

31-503 Kraków

E-mail: jadwiga.holewa@inig.pl
Metoda chromatografi gazowej z detekcja za pomoca spektrometrii mas (GC-MS).

[14] Rozporzadzenie Ministra Środowiska z dnia 9 września $2002 r$. w sprawie standardów jakości gleby oraz standardów jakości ziemi (Dz. U. z 2002 r. nr 165, poz. 1359).

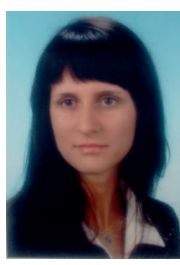

Mgr Monika Gajec

Starszy specjalista inżynieryjno-techniczny

w Zakładzie Ochrony Srodowiska

Instytut Nafty i Gazu - Państwowy Instytut Badawczy

ul. Lubicz 25 A

31-503 Kraków

E-mail:monika.gajec@inig.pl

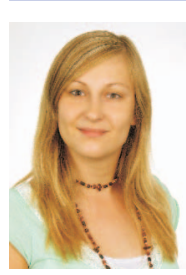

Magdalena WIŚNIECKA

Starszy specjalista badawczo-techniczny w Zakładzie Ochrony Środowiska.

Instytut Nafty i Gazu - Państwowy Instytut Badawczy ul. Lubicz 25 A

31-503 Kraków

E-mail:magdalena.wisniecka@inig.pl

\section{OFERTA}

\section{ZAKŁAD MIKROBIOLOGII}

Zakres działania:

- badania procesów mikrobiologicznych w środowisku złożowym podziemnych magazynów gazu ziemnego (PMG);

- działania prewencyjne - zastosowanie biocydów, środków typu neutralizatory $\mathrm{H}_{2} \mathrm{~S}$ oraz inhibitorów bakterii redukujących siarczany (SRB) i biogennego $\mathrm{H}_{2} \mathrm{~S}$;

- bioremediacja gruntów skażonych związkami ropopochodnymi;

- biodegradacja związków polimerowych wchodzących w skład płynów wiertniczych;

- mikrobiologiczne technologie stymulacji eksploatacji złóż węglowodorów;

- mikrobiologiczne metody poszukiwawcze: metodą powierzchniową oraz mikrobiologicznego profilowania odwiertów;

- badania testowe preparatów antybakteryjnych (biocydów);

- badania bakteriologiczne wody pitnej.

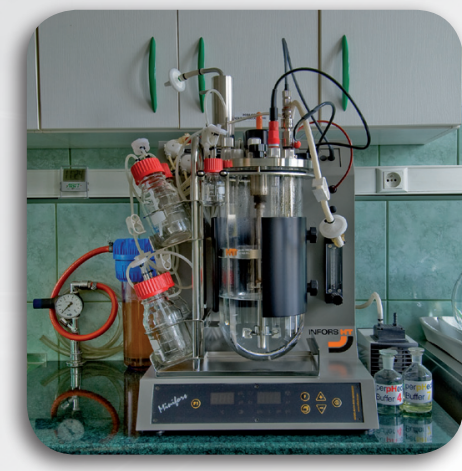

